\title{
The Credible Voice in Pedro Lemebel's Oeuvre: Identity, Gender and Censorship
}

\author{
ALEJANDRO URRUTIA
}

\begin{abstract}
The oeuvre of the recently deceased Chilean writer Pedro Lemebel (1952-2014) can be described as an expression for systematically persecuted, repressed, censored minoritarian voices, both during the Chile of the dictatorship, that is during the 1970s and 1980s, as well as afterwards, in democratic Chile, that is from the 1990s onwards. These voices build discourses where gender, class or ethnic identity become the narrative axis in Lemebel's work. His novels, chronicles, performances and short stories have been extensively distributed by alternative media such as independent community- and Internet-based television and radio channels starting in the 1990s under the democratization period post-Pinochet. In this paper, I will analyze the construction of an idea of the author throughout the Lemebelian oeuvre. This author/narrator construction is related to Jon Helt Haarder's concept of "performative biographism" to identify the set of interventions made by the author/creator in the reading process, i.e. those interferences created by the writer as a public persona and channeled through mass media that orient the reading process (Haarder 2007: 72-82). I am particularly interested in exploring how this figure of the author achieves credibility. I build the analysis mainly upon the concepts from cultural narratology, queer theory and postcolonial studies.
\end{abstract}

Keywords: modern Chilean literature; literature and performances; the idea of the author; gender; minority; narrative credibility

Me apesta la injusticia. Y sospecho de esta cueca democrática (Lemebel 2011[1986] : 218-221)

Injustice stinks. And I suspect this democratic dance (Lemebel 2015a)

\section{Pedro Lemebel, between the performative author and narrator}

To comment on the construction of a credible narrator in Pedro Lemebels work I will examine the relation between his public appearances as a writer and some features of his literature. I will pay special regard to how censorship 
determines, and sometimes even defines, his artistic production. Pedro Lemebel's work was severely conditioned by the country's military regime that lasted from 1973 to the beginning of the 1990s. Chilean dictatorship, like all the other Latin-American dictatorships that emerged just after the Cuban Revolution, originated in the aftermath of the Cold War. The main purpose of this dictatorship was to repress and annihilate forces or individuals considered enemies of the West and/or pro-Soviet. These were just the first, or just the "basic", goals of the military regimes. Their ambitions would soon be multiplied and extended, repression would diversify and target any other group that might eventually become a threat to the conservative social model defended by dictatorships.

Lemebel's oeuvre can be divided into three separate but closely related fields. There is the performative one, developed at the end of the 1980s and the beginning of the 1990s when Lemebel was part of the art collective Las Yeguas del Apocalipsis (The Mares of the Apocalypse) ${ }^{1}$. Las Yeguas performances were inscribed within a militant LGBTQ identity discourse, in their provocative and surprising appearances they challenged ideals of masculinity, sexual normativity, and canonical artistic regulations and limits (Las Yeguas del apocalipsis 2015). This was a powerful disobedient discourse which questioned repressive structures affecting groups regarded by several social actors as minorities. The normativity criticized by Francisco Casas and Lemebel emanates not only from the military regime but also from the Catholic Church and even political organizations opposed to the dictatorship as well.

The origin of this performative work is related to Judith Butler's ideas on gender performativity. On the one hand it challenges normative identity structures and on the other hand provides alternative identity models (1990: 12-13). Likewise, this effort of Lemebel to channel minorities' voices can be read in the light of Gayatri Spivak's suggestion that subaltern groups whose voice is silenced because of their non-hegemonic position within sociopolitical structures (1988: 280-290) leave this position as subaltern as soon as they are able to talk, to express themselves and to be heard.

The second field in Lemebel's work is composed of novels, short stories and chronicles. In this written part, topics and perspectives are pretty much the same as those developed for the performances, Lemebel's texts continue to question and criticize the social order. Throughout his written production, we

\footnotetext{
Wanderlan da Silva Alves (2012: 182) suggests that the name (The Mares of the Apocalypse) comes from the Bible and that that name is a parody of the Horsemen of the Apocalypse. Using this name according to da Silva Alves is a way the artists use to criticize the categories of gender of Chile at the time.
} 
find a fabric made of intertextual references (Genette 1989: 9-20) that create a continuity in the Lemebelian discourse.

Third and last, and also related to the first field, there is another kind of acting performance, the one that the author puts up when he reads/declaims his own texts, specially chronicles, where Pedro Lemebel the human being and public persona represents Pedro Lemebel the implied author and narrative voice. Within this part of his artistic production, and in consonance with Butler's ideas, Lemebel methodically builds up the image of this author which encompasses his entire oeuvre. In his readings Lemebel defends the right of non-normative identities to exist, where gayness is a central element to identity, an element which serves as a ground for the construction of the authorial image and a key element in the construction of a credible narrative voice as well. When Lemebel recites, he does much more than simply reading the texts, he keeps performing and is always engaged in a ceaseless struggle for the acquisition of civil and social rights for gay people and other vulnerable groups in society. At the same time, these performances work in the opposite direction: they boost the narrative voice in the Lemebelian literature, legitimizing his demands and vindications.

Lemebelian texts argue on the one hand against several aspects of social normativity such as class, gender, ethnicity, sexuality, and on the other hand with the always threatening censorship of the historical context. Confronting this censorship is a frequent topic in his work. Most of his chronicles, for example, are somehow concerned with this kind of conflict. Thus, there are chronicles committed to questions of memory, where the chronicler feels the responsibility to recover lost spaces and historical facts, experiences which were silenced, repressed and forgotten because of dictatorial censorship. Censorship as a theme works in the Lemebelian text as a mean to give credibility to its own narrative voice.

Lemebel breaks up with the rules of the chronicle as a genre when he transfers the narrating voice from the chronicler to the protagonists in the chronicle, he thus challenges the narrator's authority and the texts come closer to the narrative genre (Barrada 2009: 78-79). The narrator remains in first person, under the name of the author and the story is connected to a specific historical reference but with characters who speak trough their own voice. This process of narrativization of the chronicle is deepened with the addition of complex units of temporality and space. This sum of diverse voices all struggling to survive military censorship finds a channel in Lemebel's chronicles and becomes another element in the text that asserts the author's credibility. 


\section{Credibility construction}

The premise in this exploration is that all Lemebelian texts, i.e. visual performances, chronicles, short stories, novels and reading performances, are interconnected by the same image of the author. In every text, we find constantly references to the other texts written by Lemebel, remaining all intermingled in that way. The performances that have been registered by different media like photography, short video films and radio interviews, were later further transmitted and made accessible through other media like blogs, Youtube and websites.

These sorts of declamatory performances were composed of the actual reading of Lemebel's texts by Lemebel himself on the one hand, and on the other by the theatrical setting of bodily gestures, postures, diction and intonation, and other audible and visual signs which always accompanied the reading. All these expressions were linked to recurring Lemebelian themes, to recurring individuals and to recurring spaces found in his texts.

The purpose of this sophisticated intertextual system is to strengthen the Lemebelian narrator's legitimacy which gives in its turn, the credibility necessary for this narrator to build and transmit its discourse.

Lemebel's internationally best known work, the novel Tengo miedo torero (My Tender Matador, 2001) is closely related to Latin-American narrative through the genre of the guerilla novel, such as for example Omar Cabezas' La montaña es algo más que una inmensa estepa verde (Fire from the mountain, 1982), Gioconda Belli's La Mujer habitada (The Inhabited Woman, 1988); and to novels with a queer thematic such as José Donosos, El lugar sin límites (Hell has no limits, 1966) or Manuel Puig's El beso de la mujer araña (Kiss of spider woman, 1976).

My Tender Matador is a love story set in 1986 about theg main character called The Queen of the Corner and a young guerillero whose guerrilla group is organizing an attempt to kill Chile's dictator. The Queen of the Corner is represented as male, gay and transvestite (Butler). The novel shows how The Queen of the Corner, while helping Carlos' cause, develop romantic feelings for him. Carlos is a straight male university student and guerillero who does not have the same interest in The Queen and whose sexuality is apparently fixed and immobile, but who would eventually fall in love with her as well. Censorship is a recurrent topic, while their love becomes impossible because love of that kind is censored by society, the novel offers a different version of a historical moment from the official one delivered by the mass media of that time. The text describes the failed intent to assassinate the dictator Pinochet, the preparation 
during the preceding days and the moments immediately after, including the crucial information censored by the regime.

As previously mentioned, it is characteristic for Lemebel's chronicles to take on an unveiling roll, to reveal what really happened in that historic context to which the fiction refers. In the case of My Tender Matador, even if it cannot be called a testimonial novel ${ }^{2}$, this version does cast light over several historical facts of the Chile of 1986 that were distorted or left out in the official account.

Another decisive feature in the construction of credibility is that this idea of the author or this figure of the author within the Lemebelian text operates as a kind of spatial net where characters exist, dwell and act. Lemebel has accomplished an image of the author intrinsically related to the spaces present in his texts; for instance, when he writes about poverty and marginality he often sets the narrative action in Zanjón de la Aguada, the same shantytown in Santiago where the author grew up. Lemebel thus succeeds in matching up the spaces from where his discourse is transmitted with the fictional spaces of his texts. The presence of Lemebel as a human being and public persona in the narrative spaces blurs the limits between fiction and reality and amplifies the credibility of the other characters, their ideas and actions. The author has worked on this image through his public performances where he acknowledges directly the space where he stands, the space from where the message is delivered. Once those spaces are known and secured as "real", they become fictional spaces in his texts. In that way, performances have left signs and traces, some clearer than others, which the readers or audience later encounter during their own reading.

In the case of The Queen of the corner in My Tender Matador, this idea of the author created by Lemebel is the element that gives legitimacy to the novel's ideological discourse and disrupts the narrative's status as fiction, getting the text closer to the genre of chronicles and the testimonial novel because The Queen corresponds to the idea of author built by Lemebel. Censorship is exposed as what is narrated originates from a participant and a witness of the real facts - Pedro Lemebel - who in the novel is The Queen and a trustworthy narrator. The novel seeks to show that those people involved in the attack on the dictator and presented by the censorship apparatus as dehumanized figures were in fact perfectly normal people.

I have already mentioned that this novel contains an intertextual dialog with the genre known as the guerrilla novel. This dialog is critical; for example, in My Tender Matador, The Queen is both the main character and the hero of

2 The term is used as presented by Anna Forné in "La Historia en la narrativa hispanoamericana contemporánea” (2013: 264-268). 
the story. This character has a non-normative identity, an alternative identity that disagrees with the usual features of the guerrilla hero, who is regarded as ideologically conscious and consistent, militant in a Marxist organization and preferably male and heterosexual. This dialogue seeks to question the normative gender tradition in which the previous novels were structured, and to discuss these matters within the social context in general but specifically within the context of the Latin-American left. In 1986, during a congress called by several leftist Chilean political organizations and still during the dictatorship, Pedro Lemebel reads "Manifiesto, hablo por mi diferencia" (Lemebel 2005) where he acknowledges and challenges the rejection the revolutionary groups express towards gay people and wonders which role people with LGBTQ) identities could play in the still imagined and longed for society post-dictatorship. In this text structured as a poem, there is a militant poetic voice whose addressee is a collective, a leftist political party which is not named directly, but can be guessed to be the Communist Party by references such the use of a specific jargon (reactionary propaganda, proletariat, party, free fatherland, Marxism); Lemebel demands equal rights for "economic, racial and sexual minorities without taking traditional political positions into account" (Hueso, 2012: 292-293). This manifesto, which was later published in 1997, was censored by the official press, and (in accordance with what Lemebel expresses in the Manifesto) was also censored by militants in the party, the party to which both the author and the poetic voice belong.

In My Tender Matador, the intertextual connections with the novel of the guerrilla are conditioned and marked by this Manifesto, because The Queen matches precisely and establishes continuity with the poetic voice of Lemebel's speech in the congress of 1986. This strategy is part of the consistent construction of the Lemebelian voice I have pointed out, a voice characterized by central and recurrent elements which are constantly interwoven. The manifesto is a key and initial point, where the fundamentals of the Lemebelian discourse can be found, challenging class, sexual normativity, and social injustice, and advocating the struggle for social rights and the positing of alternative identities.

Even if the main topic of the Manifesto is to demand an authentic space for a gay identity, which is also one of the most salient features of the Lemebelian discourse; the credibility of this voice is built upon a premise that posits it as a specific individual demand, but one that is in consonance with many other voices. To fully grasp Lemebelian discourse it is crucial to understand this principle that leads the Lemebelian voice throughout his entire narrative: "I am just one more voice within an ocean of voices, but it is still me, Pedro Lemebel, who is talking." 
The novel My Tender Matador was published in 2001, almost fourteen years after the Manifesto was first read in 1986. From the reading to the year when his only novel was published, Lemebel had steadily built up an authorial image through the reading performances where he materializes the narrator of the chronicles in his own voice. This narrative voice in the chronicles is identical with the ones used in the novel and easily recognized by the reader. There are two distinctive narrators in My Tender Matador, one extradiegetic and one intradiegetic, which is The Queen; both remind the reader constantly of the narrator of the chronicles and thus of Pedro Lemebel himself. For exemple in "A Kind of Synopsis" the narrator says, "I could write clearly, I could write without so many nooks and crannies, without so many useless twists and turns" (Lemebel 2015), that is, the same narrative tone.

Even though the description of The Queen differs from the author's image in many respects -for example in the physical appearance of the character - there are several similarities that can be found between the author and his performances. When it comes to the external narrator of the novel, the resemblances with the chronicle's narrator can be detected using recurring perspectives, narratives modes, expressions, symbols and metaphors. Hence, this Lemebelian narrative voice that exceeds the texts but is present in all of them is made up of the repetition of a narrative action which consists in repeating topics, places, characters and ways of storytelling.

In My Tender Matador, there is a paratextual (Genette: 1989: 9-20) mark, an introductory note where the author contextualizes the following story, once more using the characteristic Lemebelian voice. The purpose of this explanation is to frame the fiction within the ideological aspects of Lemebel's oeuvre, the text is thus queered from the very beginning: "This book emerged out of twenty pages written at the end of the 1980s and mislaid for years among fans, lace stockings and cosmetics that smeared with rouge the balladizing calligraphy of its script" (Lemebel 2003: 0), moreover, it makes clear that the fiction has truthful starting points.

\section{Credibility and the idea of author}

The chronicles comprised the biggest portion of Lemebel's artistic production. These texts were originally made public by the author in performances arranged in several cultural centers engaged with social work, and later through radio broadcasts by ONG channels with substantial audiences such as Radio Tierra. In the second half of the 1990s Lemebel's work gained wide recognition within the local cultural scene, specially his written texts attracted attention and he 
URRUTIA

became a celebrated author within Spanish literature in general. Thus, the chronicles were published in another type of media, newspapers with a much larger reach such as El Clarin in Argentina and The Clinic and La Nación in Chile. Several collections of chronicles were also published by significant editorial houses such as Anagrama, Seix Barral and Sudamericana for exemple Adiós mariquita linda (2006) and Serenata cafiola (2008).

One of the fundamental aspects of the idea of the Lemebelian author is credibility, the way this figure gains credibility and thus political power through his different performances where he takes on the responsibility to talk for repressed minorities, first for those repressed by dictatorship and then for those repressed by society in general. If in the first chronicles and performances a kind of homogeneous body of the oppressed can be distinguished, that is a group made up of all those that were against the dictatorship. Later, with the transition from a military regime to a pseudo-democratic one, this body is dispersed and results in the Lemebelian minorities, unities such as boys, girls, women, prostituted men, AIDS infected people and mapuche people. The Lemebelian voice always expresses an alternative to the prevailing normative system. It is queer because it represents an unconventional narrative to the nation, not only to the normativity imposed by dictatorship, but even the one underlying dictatorship, the one that was already there before the military took power, the constrained normativity that grounded the patriarchal and authoritarian regime.

The credibility of the Lemebelian voice is thus built around the author's own identity. Related to the importance of the Lemebelian identity is the question of key spaces and places that are fundamental for his work. One of the collections of chronicles is named after one of those places, an emblematic political, social and geographic space of Chile of the last 50 years: El Zanjón de la Aguada area.

\section{Lemebel and Zajón de la Aguada}

Pedro Lemebel was born in 1952, he comes from one of the most vulnerable social sectors of the Chile of that time, since his numerous family is of the indigenous Mapuche descent, and by the time of his birth they lived in Santiago's poorest area, by the Zanjón de la Aguada, the watercourse that gives its name to the area and that runs across the city starting at the foot of the Andes mountains westward to the Maipú area. Hundreds of shacks and precarious houses were built by the watercourse during the decades up to the 1990s, when it was finally cleansed and big portions were enclosed underground. 
The material conditions of this semi-rural strip of poverty that surrounded Santiago were desperate: floors were often made of clay, the walls of corrugated cardboard, the roof of zinc or fonola (a kind of tar and pressed paper), all built following the line of the watercourse across the city. From a bird's eye view, you can see the crystal-clear water coming from the melted ice in the Andes entering the city and nurturing it, and you can see as well how the transparent serpent becomes a brown cloak that also nurtures the city. The watercourse was first modified to make the irrigation of old Santiago's orchards possible. Although soon, following the model of urban expansion, the green areas were gradually transformed into buildings.

Zanjón de la Aguada is one Lemebel's most significant spatial referents and serves as the common thread that runs through all his works. This area was first occupied in 1946 by poor working class families evicted from the city tenements (Cury 2014: 223-49). This occupation was one of first organized in Latin America, and was the origin of the emblematic neighborhood called Población la Victoria (Sepúlveda Swatson 1998). This was one of the areas that the military most fiercely repressed, and one of the main focuses of organized resistance.

Zanjón de la Aguada-space is for Lemebel's work a representational space as described by Henri Lefevbre i. e. the combination of a place where the inhabitants can recognize themselves and the space created by artists to describe and to understand their reality, but also the space where power relations are expressed clearest (Lefevbre 1991: 41). Several of his characters mention this space or refer to in indirectly (Franco 2010: loc 670), but the constructed idea of the author Pedro Lemebel is the ground for this reference and vice versa. When Lemebel points out that "I speak from my homosexuality, from the proletarian, from the urgency to express a political desire" (Lemebel 2011), he establishes the origin of his discourse in the space that is Zanjón de la Aguada. Lemebel establishes a foundational link between the spaces of poverty, marginality, overcrowding and sexual identity and Zanjón, and then uses this link to ground the idea of the author. The Lemebelian hero/heroine comes from this marginal space of Santiago, and we see him/her acting in the narratives as loyal to that origin, i. e that their characterizations are consistent with the importance of that origin, Zanjón is a source that conditions their actions. The space of the Zanjón de la Aguada is therefore another component in the credibility of the narrator, because it legitimates him as a spokesperson for the accusations, complaints and demands of the characters he represents.

It is important to clarify that not all Lemebel's texts explicitly name the Zanjón de la Aguada, what is stable, however, is the narrator, expressed as Pedro Lemebel or The Queen, who is born in Zanjón. In an interview telling 
URRUTIA

about his childhood Lemebel says "Rats were my stuffed toys" (Lemebel 2011), transforming an expression of extreme poverty to an expression of tenderness, "[a]nd if one says that saw the first light of the world, who intressed, who cares?" (Lemebel 2003: 13).

\section{Summary and examples}

Hitherto I have pointed out that the credibility of the author/narrator is based on, first, an effort to create a voice that is the collective voice for different minorities in society. Secondly, these minorities empower themselves in the fiction, challenging fossilized social values and contesting unbalanced power relations using their own voice, and thus emerging from a subaltern position the subversive agency of these groups is also part of part of the performance of identity

Lastly, credibility is built up through the performances together with the public appearances of Lemebel, where he transitions through the same spaces his characters do, the same spaces from where they enact their identities and challenge normativity and social injustice. Lemebel's appearances and interventions create a constant interference between his readers and his texts, making it impossible for the reader to ignore this and not to take the interference into account, a phenomenon that Helt Haarder calls "performative biographism" (Haarder 2007: 72-82).

Credibility is thus produced by the integration of historical references with fictional ones, mediated by the Lemebelian voice which is constructed through the performative work of the author, and serves as a channel for minorities engaged in destabilizing normativity and modifying how minorities are perceived.

Credibility makes it possible for the Lemebelian voice to show how things really are and to unmask historical matters previously marked by censorship. The characteristic features of the chronicle as an informative genre anchored in real facts, reinforce this credibility, making the work of explanation easier for the Lemebelian voice. Credibility is secured through the strong authorial image which is possible thanks to the massive reach of mass media, which materializes his presence outside the literary text. Lemebel thus employ what can be called a trend in contemporary westernized-globalized culture, i. e the familiarization of the audiences with public people (sport stars, intellectuals, participants in reality-shows, actresses and actors, and so on) by means of their totalizing presence in mass media. 
The Credible Voice in Pedro Lemebel's Oeuvre: Identity, Gender and Censorship

In the "Manifesto" the narrator targets a collective recipient of the message and advocates for the acceptance of the gay militant within revolutionary organizations. The discrimination and persecution proceeding from inside the organizations and suffered by gay militants is thus addressed. These kinds of demands are present in all Lemebelian texts and are essential to the author's voice.

That is the case of the chronicle "The Unicorn Misunderstanding"3 "La pesquisa y careo a Silvio Rodríguez, o el malentendido del unicornio" (Lemebel 2002), where he incorporates into the text a typical authorial gesture from his performances, he pauses the reading to fix his hair, and then continuous as usual:

[...] My friend and I are Chilean admirers of your poetry, and in Chile we the homosexuals have done "The blue unicorn" our song, thinking that it might be about a lost and impossible love. (Pause to fix my hair). I would like also to use this opportunity to ask what you think about homosexuality and revolution, could you please answer me those questions) $[\ldots]^{4}$

This chronicle illustrates the widespread reactionary attitude that the LatinAmerican left displayed towards gayness at the end of the 1980s. In the text, the narrator plays with another text, the lyrics of "Unicornio" (Unicorn) probably the most well-known song by the famous Cuban troubadour Silvio Rodriguez, an icon for the entire Latin-American left. Lemebel reads the blue unicorn in the lyrics as a metaphor for the search for a gay identity (Franco 2004: 22).

Years later, Silvio Rodriguez would give an irritated answer to that chronicle and pull it out from its contextual fiction:" I received today a letter from the chronicler, where he attaches a fragment from a book which alludes to me. This is an absurd invention made by a Chilean author I did not know (I know now he is famous), with a writing stylistically influenced by Before night falls by Reinaldo Arenas [...]" (Rodriguez 2009). Rodriguez' answer serves as an example of one possible reading of Lemebel's text, the musician is emphasizing the inventive character of the chronicle, a kind of reading that itself points towards the effectiveness of the relation between Lemebelian performances, his

\footnotetext{
My own translation.

4 My own translation. [...]Mi amigo y yo somos chilenos que admiramos tu poesía, y en Chile nosotros los homosexuales hemos hecho nuestra la canción del Unicornio Azul, pensando que se refiere a un amor perdido e impossible. (Pausa para arreglarme el pelo). También quiero aprovechar la ocasión para preguntarte qué piensas tú sobre la homosexualidad y la revolución ¿Me podrías contestar estas preguntas por favor? [...]
} 
public persona and his texts. Most important in this context is the information given in parentheses "pause to fix my hair", here the text jumps out and points directly towards the writer's identity. That textual gesture is to be interpreted as related to the previous performances where he actually pauses the speech and fixes his hair, performances where he might even have read this very chronicle, creating thus a circular flow of intertextuality and intermediality (Grishakova 2010: 333-42).

\section{Conclusion}

In the previous pages, I have shown that in Lemebel's oeuvre there is a constant concern in creating a voice that resembles the voice of certain minorities. In his narrative, these minorities speak for themselves and make demands, integrated by subjects that move in the margins, that dwell in spaces severely constrained by social structures, structures that bound them to inhabit the spaces they belong to without ever making possible for the spaces to belong to them (Bhabha 1994: 1-2, 9). Lemebel materializes this voice and makes it audible. For example, in the chronicle "Help! I got lost in a shopping mall (or, do you have band aids?)" "Socorro, me perdí en un mall (O, ¿tiene parche curita ?)" (Lemebel 2008), a male narrative voice enters one of Santiago's many shopping malls to buy a band aid. As he is wandering around and searching for the band aid, the narrator makes a critical reading of the modern neoliberal market space. He describes it as in contrast with the outdoors, there is in the story a clear border line between the exterior and interior. For example, there are guards that stop people who "do not fit in" from entering the mall, like beggars or peddlers. The space is described as a futuristic dystopia in which the characters walk like zombies and the children get lost and wander around. Exhausted after exploring the whole mall without finding what he was looking for, the narrator finds "In a gutter, a woman who smiles at [him] humbly, and with a contraband-streetgrace she asks me "Sir, would you like to buy some band-aids?" 5 (Lemebel 2008)

Further, lemebelian characters destabilize normative conceptions of identity, as in the love story between the Queen and the FPMR ${ }^{6}$ soldier Carlos in My Tender Matador. Ultimately, Carlos falls in love with her and even though he does not ever really change his own conception of love in general, he

5 My own trasnlation. “ [...] en la cuneta, humildemente una mujer me sonríe ofreciéndome con su gracia de contrabando callejero : ¿no va a llevar parche curita señor ?”.

6 FPMR, (Patriotric Front Manuel Rodríguez) was an armed organization opposed to the dictatorship integrated mainly by young people. 
The Credible Voice in Pedro Lemebel's Oeuvre: Identity, Gender and Censorship

acknowledges that love. If we accept the relationship between the narrator and author's public persona and the author's idea born of this relationship, then we can easily recognize Lemebel in The Queen's character. In several of Lemebel's performances and chronicles we find passages where the narrator jokes about his preference for younger men and about his profound ideological convictions, the same behavior as The Queen. Her thoughts, her musical taste, her clothing tastes match those shown in the chronicles, and these matches function to characterize The Queen.

Finally, the relationship established between the referential space Zanjón, the performance work done with Las Yeguas and the performative reading of the chronicles, leave textual traces in the written narrative which are induced by the idea of the author, an authorial voice whose purpose is to build credibility to legitimate his discourse as representative of groups that are socially subjugated and that now claim justice.

\author{
Alejandro Urrutia \\ alejandro.urrutia@miun.se \\ Avdelningen för humaniora \\ Mittuniversitetet \\ 85170 Sundsvall \\ SVERIGE / SWEDEN
}

\title{
Bibliography
}

Barrada, E. 2009. Para travestirte mejor: Pedro Lemebel y las lecturas políticas desde los márgenes. - Iberoamericana, IX, 33, 69-82.

Belli, G. 1999 [1988]. La Mujer habitada. Navarra: Txalaparta.

Belli, G. 2004. The Inhabited Woman. Transl. by K. March. Madison: University of Wisconsin Press.

Bhabha, O. 1994. The Location of Culture. Routledge: London.

Butler, J. 1990. Gender Trouble: Feminism and the Subversion of Identity. New York: Routledge.

Cabezas, O. 1982. La montaña es algo más que una inmensa estepa verde. México: Siglo XXI.

Cabezas, O. 1985. Fire from the mountain: The Making of a Sandinista. Transl. by K. Weaver. New York: New American Library.

Cury, M. O. 2014. Occupying spaces, constructing identities: the importance of the movement of pobladores for the political and social history of Chile (19501970). - Revista Brasileira de História, 34 (67), 223-249.

Donoso, J. 1966. El lugar sin límites. México: J. Moritz. 
URRUTIA

Donoso, J. 1995. Hell Has No Limits. Los Angeles: Sun \& Moons Press.

Forné, A. 2013. La Historia en la narrativa hispanoamericana contemporánea. Historia de las literaturas hispánicas: aproximaciones críticas. Stokholm: Studentlitteratur, 257-277.

Franco, J. 2004. Estudio preliminar. Encajes de acero: la libertad bajo vigilancia. F. A. Blanco, ed., Reinas de otro cielo: modernidad y autoritarismo en la obra de Pedro Lemebel. Santiago: LOM Ediciones, 11-23.

Franco, J. 2010. Pedro Lemebel. El perpetuo enamorado. - F. Blanco, J. Poblete, eds., Desdén al infortunio. Sujeto, comunicación y público en la narrative de Pedro Lemebel. Santiago: Cuarto Propio, Kindle edition, loc. 651-752.

Genette, G. 1989 [1982]. Palimpsesto. La literatura en Segundo grado. Madrid: Altea, Taurus, Alfaguara.

Guha, R., Spivak, G., eds. 1988. Selected Subaltern Studies. Oxford: Oxford Univ. Press.

Grishakova, M. 2010. Intermedial Metarepresentations. - M.-L. Ryan, M. Grishakova, eds., Intermediality and Storytelling. Berlin, Boston: De Gruyter, 333-353.

Haarder, J. H. 2007. Ingen Fiktion. Bara Reduktion. Performativ Biografism som Konstnärlig Strömning Kring Millenieskiftet. - Tidskrift För Litteraturvetenskap, 37 (4): 77-92.

Hueso, S. 2012. Ya no estás más a mi lado, corazón: Estética Kamp en América Latina. Valencia: Universidad de Valencia.

Las Yeguas del Apocalipsis. 2015. http://www.yeguasdelapocalipsis.cl/biografia/ (10.01.2015).

Lefebvre, H. 1991. The production of space. Oxford: Basil Blackwell.

Lemebel, P. 2001. Tengo miedo torero. Anagrama. Barcelona.

Lemebel, P. 2003. My Tender Matador. Transl. by K. Silver. New York: Grove Press.

Lemebel, P. 2005. Manifiesto (Hablo por mi diferencia). - http://lemebel.blogspot. com.ee/2005/11/manifiesto-hablo-por-mi-diferencia.html (30.03.2017).

Lemebel, P. 2006. Adiós Mariquita linda. Santiago: Sudamericana.

Lemebel, P. 2002. Pesquisa y careo a Silvio Rodriguez. El malentendido del unicornio. http://edant.clarin.com/suplementos/cultura/2002/11/16/u-00301.htm (10.11. 2015).

Lemebel, P. 2008. ¿Tiene parche curita?O Socorro me perdí en un mall. - http://www. fotolog.com/theclln1c/32564065/ (12.03.2015).

Lemebel, P. 2011 [1986]. Hablo por mi diferencia. - Revista Anales, 2, 218-221.

Lemebel, P. 2003. Zanjón de la Aguada. Barcelona: Seix Barral.

Lemebel, P. 2008. Serenata cafiola. Barcelona: Seix Barral.

Lemebel, P. 2011. Trazo mi ciudad. - http://www.trazomiciudad.cl/2011/08/pedrolemebel/ (30.03.2017).

Lemebel, P. 2015a [1986]. Manifesto. I Speak for My Difference. - http://cordite.org. $\mathrm{au} /$ poetry/notheme4/manifesto-i-speak-for-my-difference/ (12.01.2015).

Lemebel, P. 2015b. A kind of synopsis. - http://cordite.org.au/poetry/notheme4/akind-of-synopsis/ (30.03.2017).

Puig, M. 1979. Kiss of Spider Woman. Knopf. New York: Random House.

Puig, M. 1994 [1976]. El beso de la mujer araña. New York: Random House. 
The Credible Voice in Pedro Lemebel's Oeuvre: Identity, Gender and Censorship

Rodriguez, S. 2009. Silvio Rodriguez desmiente a Pedro Lemebel. - PD. Asuntos Cubanos, http://www.penultimosdias.com/2009/01/17/silvio-rodriguez-desmiente-apedro-lemebel/ (11.03.2015)

Sepúlveda Swatson, D. 1998. De tomas de terreno a campamentos : movimiento social y político de los pobladores sin casa, durante la décadas del 60 y 70 , en la periferia urbana de Santiago de Chile. - Boletin INVI, 35, Chile, Noviembre, V 13, 103-115.

Da Silva Alves, W. 2012. Fronteras del deseo : melodrama y crítica social en Tengo miedo torero, de Pedro Lemebel. - Castilla. Estudios de Literatura, 3, 181-204.

Spivak, G. 1988. Can the Subaltern Speak? - C. Nelson, L. Grossbeerg, eds., Marxism and Interpretetation of Culture. Basingstoke: Macmillan Education, 271-313. 